\title{
血液製剤輸血の適応と使用法
}

\section{3. トロンボモジュリン製剤：リコモジュリン}

Thrombomodulin

鈴木宏治*

Kohji SUZUKI*

Key words : thrombomodulin, protein $\mathrm{C}$, disseminated intravascular coagulation, DIC

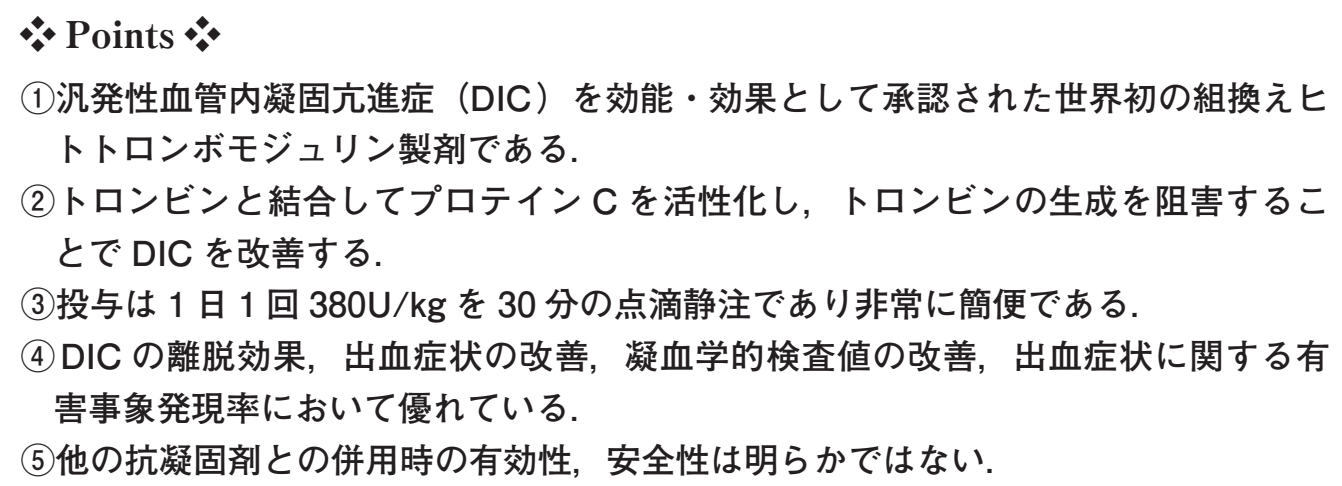

(1)沉発性血管内凝固立進症（DIC）を効能・効果として承認された世界初の組換えヒ トトロンボモジュリン製剤である.

(2)トロンビンと結合してプロテインC を活性化し，トロンビンの生成を阻害するこ とでDIC を改善する.

(3)投与は 1 日 1 回 $380 \mathrm{U} / \mathrm{kg}$ を 30 分の点滴静注であり非常に簡便である.

(4)DIC の離脱効果, 出血症状の改善, 凝血学的検査值の改善, 出血症状に関する有 害事象発現率において優れている.

(5)他の抗凝固剤との併用時の有効性, 安全性は明らかではない.

\section{1. はじめに}

トロンボモジュリン（TM） は，1982 年米国の Esmon らによりウサギ肺の血管内皮細胞から単 離された高親和性トロンビン結合蛋白質であり, トロンビンによる凝固制御因子プロテアーゼ前駆 体のプロテイン C の活性化を促進する補助因子 (トロンビンのモジュレーター：thrombomodulin) として命名された ${ }^{1)}$. トロンビン一 TM 複合体の 限定分解を受けて生成される活性化プロテイン C ( $\mathrm{APC})$ は, 凝固カスケード補助因子の第 $\mathrm{V}$ a 因 子と第 VIII a 因子を分解・失活化し，トロンビンの 生成を阻害する。また，TM はそれ自体がトロン ビンの凝固促進活性（フィブリノーゲン凝固，第 $\mathrm{V}$ 因子活性化，血小板活性化など）を直接阻害す
る作用を示す。その他にも線溶阻害活性や癌の増 殖阻害活性，レクチン様ドメインを介した抗炎症 作用など多面的機能を持つことが報告されてい る.

1987 年にヒト TM の全 cDNA 構造が解明され, $\mathrm{TM}$ 前駆体は 18 アミノ酸のシグナルペプチドを 含む 575 アミノ酸残基からなり，成熟 $\mathrm{TM}$ は，5 個の特徵的な構造 $\mathrm{NH}_{2}$ 末端レクチン様ドメイン, 6 個連続する EGF 様ドメイン, O 型 ( Ser/Thr) 糖鎖結合ドメイン, 細胞膜貫通ドメイン細胞質ド メイン」から構成されていることが明らかになっ た $^{2)}$. また, EGF 様ドメインの後半の 3 個の構 造がトロンビンと結合してプロテイン C を活性 化することが明らかにされている.

この生理的に重要な抗血栓性蛋白質を抗凝固薬

*三重大学大学院医学系研究科分子病態学〔干 514-8507 津市江戸橋 2-174〕

Department of Molecular Pathobiology, Mie University Graduate School of Medicine

[2-174, Edobashi, Tsu, Mie 514-8507, Japan]

Tel: 059-231-5036 Fax: 059-231-5209 e-mail : suzuki@doc.medic.mie-u.ac.jp 
として臨床応用するため, 約 20 年前から遺伝子 組換え技術を用いて作製された TM の細胞膜外 の 3 つのドメイン（498 アミノ酸）を含む可溶性 蛋白質 ${ }^{3)}$ の臨床試験が行われ，2007 年成功裏に 終了した ${ }^{4)}$ 。そして，2008 年 5 月，本邦に打い て，世界初の遺伝子組換えヒトトロンボモジュリ ン製剤であるリコモジュリンが，沉発性血管内凝 固充進症（DIC）の治療薬として承認された。

\section{2. 作用機序}

DIC は，重症感染症，造血器悪性腫瘍，固形 癌などの重篤な基礎疾患に合併する。その発生機 序は基礎疾患により異なるが，共通するのはトロ ンビンの過剩生成が起こることである。その結 果，全身の微小血管内に血栓を生じ，微小循環障 害により藏器障害，あるいは線溶系の異常元進と 消費性凝固障害により出血症状を来たす。リコモ ジュリンは，天然の TM と同様に，トロンビン によるプロテイン C の活性化を促進する。その 結果生じた活性化プロテイン C (APC) は，凝 固第 $\mathrm{Va}$ 因子及び凝固第 VIII 因子を不活化するこ とによってトロンビンの生成を抑制し，血液凝固 系の活性化を阻害する。

\section{3. 用法・用量}

「リコモジュリン点滴静注用 12800」は，トロ ンボモデュリンアルファ（遺伝子組換え）とし て $12800 \mathrm{U}$ を含有する凍結乾燥製剂である。通 常，成人には 1 バイアル $(12800 \mathrm{U})$ 当り $2 \mathrm{ml}$ の 日局生理食塩水で溶解し, 体重あたりの必要量 $(380 \mathrm{U} / \mathrm{kg})$ を $100 \mathrm{ml}$ の日局生理食塩水に希釈し, 1 日 1 回 30 分かけて点滴静注する。なお, 症状 に応じ適宜減量する。

\section{4. 薬物動態}

健康成人男子にリコモジュリン $1900 \mathrm{U} / \mathrm{kg}$ を 2 時間かけて静脈内持続投与したとき，血漿中 のリコモジュリンは，投与終了後に $\mathrm{Cmax}$ に達 し，その後 2 相性で消失した（T1/2 $\alpha$ 約 4 時間, $\mathrm{T} 1 / 2 \beta$ 約 20 時間).
また，投与されたリコモジュリンは，その多くが 代謝を受けず，未変化体のまま尿中に排泄される と考えられた。

\section{5. 臨床効果}

第 III 相試験は，旧厚生省 DIC 診断基準に基づ いて DIC と診断された（DICの基礎疾患が造血 器悪性腫瘍あるいは感染症）患者 232 例を対象 に実施された ${ }^{4)}$.リコモジュリン $(380 \mathrm{U} / \mathrm{kg}$ を 1 日 1 回 30 分静脈内持続投与), あるいはへパリ ン $(8 \mathrm{U} / \mathrm{kg} / \mathrm{hr} 24$ 時間静脈内持続投与) のいずれ かが 6 日間実施された。リコモジュリン群とへパ リン群における DIC 離脱率の差の点推定值 (95\% 信頼区間）は $16.2 \%(3.3 \% \sim 29.1 \%)$ であり，非 劣性が検証された。また, 出血症状の経過におい て優れており $(\mathrm{p}=0.0271)$, 同時に出血症状の消 失率も高いという結果であった。凝血学的検査值 (TAT, D- ダイマー，PAI-1）についても高い改 善効果を示した。

\section{6. 安全性}

投与期間中 7 日目までの出血症状に関連する 有害事象は，リコモジュリン群で 116 例中 50 例 (43.1\%)，へパリン群で 115 例中 65 例 $(56.5 \%)$ であり，リコモジュリン群で有意に低いという結 果であった $(\mathrm{P}=0.0487)$.

臨床試験における副作用は，279例中 36 例 (12.9\%) に認められた。主な副作用は，血清 $\mathrm{AST}$ (GOT) 上昇 10 例 $(3.6 \%)$, 血清 ALT (GPT) 上昇 8 例 $(2.9 \%)$, カテーテル留置部出 血 7 例 $(2.5 \%)$, 尿沈椬赤血球 5 例 $(1.8 \%)$ であっ た.なお,重大な副作用として肺出血 1 例 $(0.4 \%)$ が認められている.

\section{7. 抗凝固薬の中における位置づけ}

本邦においてこれまでに多くの抗凝固薬が DIC を対象疾患として開発され，その殆どがへパリン を対照薬とした臨床試験を実施し承認されてきた という経緯がある。その中で, リコモジュリンは, ヘパリンに対する非劣性が最も明確に検証されて 
いるばかりでなく, 出血症状の改善や凝血学的検 查值の改善，出血症状に関する有害事象発現率等 についても優れていることが示されている. 現時 点で，DICに対して最もしっかりとした臨床試 験のエビデンスを持つ抗凝固薬であると考えら れる.

\section{8. 使用にあたっての注意}

リコモジュリンの効能・効果は汎発性血管内 血液凝固症（DIC）全般であるが，臨床試験にお いて造血器悪性腫瘍あるいは感染症以外の基礎 疾患の患者についての使用経験は少ない。また， 添付文書上で投与期間の規定は無いが，臨床試験 において 7 日間以上の投与経験は無いため，7 日 間以上の投与を検討する場合は，基礎疾患の病 態，凝血学的検查值および臨床症状から血液凝 固六進状態にあるか否かを総合的に判断した上 で実施する必要がある。さらに，リコモジュリ ンは主として腎臓から排泄されるため, 重篤な 腎機能障害のある患者では, 症状に応じて適宜 130U/kg に減量して投与する必要がある.また, 血液透析療法中の患者には必ず $130 \mathrm{U} / \mathrm{kg}$ に減量 して投与する. 130U/kg は用量設定試験におい
てリコモジュリンの有効性が認められた用量であ る。また，臨床試験では薬剤の効果を正確に判定 するため他の抗凝固剤を併用禁止としたため，他 の抗凝固剂との併用時に打ける効果や安全性に係

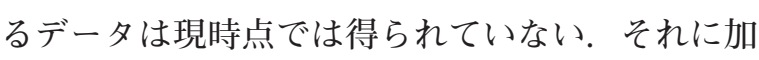
えて, 抗凝固作用が相加的に増強する可能性も考 えられるため，他の抗凝固剤との併用に際しては 慎重な判断が必要である。

これらの注意点については，今後，市販後調査 に抏いてデータを集積して明らかにして行く必要 がある.

\section{文 献}

1) Esmon NL, Owen WG, Esmon CT : Isolation of a membrane-bound cofactor for thrombin-catalyzed activation of protein C. J Biol Chem 257 : 859-864, 1982.

2) Suzuki K, Kusumoto H, Deyashiki Y, et al : Structure and expression of human thrombomodulin, a thrombin receptor on endothelium acting as a cofactor for protein $\mathrm{C}$ activation. EMBO J 6 : 1891-1897, 1987.

3) Suzuki K, Hayashi T, Nishioka J, Zushi M, Honda K, Yamamoto $\mathrm{S}$, Hashimoto $\mathrm{S}$ : A domain composed of epidermal growth factor-like structures of human thrombomodulin is essential for thrombin binding and for protein C activation. J Biol Chem 264 : 4872-4876, 1989.

4) Saito H, Maruyama I, Shimazaki S, et al : Efficacy and safety of recombinant human soluble thrombomodulin (ART-123) in disseminated intravascular coagulation : results of a phase III, randomized, double-blind, clinical trial. J Thromb Haemost 5 : 31-41, 2007. 